\title{
9 \\ Tribal data sovereignty: Whakatōhea rights and interests
}

\author{
Maui Hudson, Dickie Farrar and Lesley McLean
}

\section{Introduction}

The vast array of activities that tribal organisations in Aotearoa/ New Zealand are responsible for illustrates the importance of high-quality information to support their decision-making. Tribal information needs encompass a broad range of domains, types of information and processes for management. This chapter examines the growing iwi (tribal) interest in data and their uses in the context of one iwi, Te Whakatōhea, to explore how iwi are beginning to conceptualise their rights and interests over data in Aotearoa/ New Zealand. It is focused on the Whakatōhea Māori Trust Board and how it is collecting and becoming the steward for a range of administrative datasets, health and social service records, commercial information, historical accounts, indigenous knowledge, strategy documents and research. The tribe has recognised that robust planning will create a strong foundation for taking advantage of investment opportunities and this is based, in part, on the provision of quality information to governors to create more transparent decision-making processes. Each year the data and information needs of the tribe increase as we strive to improve our businesses and our services and to uplift our nation. 


\section{What is driving iwi interest in data?}

\section{Growing role of iwi}

Māori consider themselves to be tangata whenua-people of the land - and, as such, tribes have always had a responsibility to look after and protect both their tribal estate and their people. Both land resources and people are necessary to sustain and grow tribal identities, histories and traditions. Despite the damaging effects of colonisation, the confiscation of land, the loss of language and the urbanisation of the population, tribes have maintained their standing as a cornerstone of cultural identity and as advocates for self-determination. The obligation to sustain culture, sustain people and sustain the land motivated the fight against the Crown to gain recognition and compensation for historical injustices. There is growing momentum around the treaty settlement process, which has led to increasing interest in the role that tribes will play in society in the post-treaty settlement phase.

Over time, tribal entities and structures have become more complex as the relationship between tribes and the Crown has evolved. Traditional leadership structures sit alongside and have become intertwined with contemporary structures comprising an intricate web of land trusts, incorporations, Māori trust boards, runanga (assembly or gathering), urban authorities and statutory boards. Tribal representation on an increasing number of cogovernance entities and committeesfor example, Waikato River Authority, ${ }^{1}$ Tupuna Maunga o Tamaki Makaurau Authority (Auckland Council 2016), Rangitaiki River Forum (Bay of Plenty Regional Council 2016) and the Independent Māori Statutory Board ${ }^{2}$ - is providing a foundation for involvement in a greater number of decision-making contexts. The requirement to make robust and enduring decisions increases the need for high-quality information, and many of these entities have dedicated secretariats and/or technical advisory groups. The key features that distinguish postsettlement tribal entities from presettlement tribal entities relate to political and economic influence. Political influence increases through formal mechanisms such as co-governance arrangements,

\footnotetext{
See: waikatoriver.org.nz/.

2 See: imsb.maori.nz.
} 
comanagement functions and relationship agreements that provide statutory support for tribal participation in policy direction and resource allocation. However, influence is also enhanced by the mere fact that settlement allows the tribe to divert a greater portion of its intellectual and economic resources towards tribal development and advocacy.

\section{Growing economic influence}

Economic influence has been enhanced through the provision of direct resources (settlement funds, first right of refusal on Crown property), which allows the tribal entities to advance their economic aspirations and partner with other players in the commercial realm. With the total value of settlements to date exceeding NZ\$1 billion, this has contributed significantly to increasing tribal engagement in the economy. Over time, this has translated into increased asset bases - for example, Waikato-Tainui and Ngai Tahu, two of the earliest tribes to settle with the Crown, have turned NZ\$170 million settlements into asset bases worth NZ\$1.1 billion (Smellie 2014) and NZ\$1.075 billion (Te Rūnanga o Ngāi Tahu 2014), respectively. They have also developed innovative mechanisms to encourage financial literacy and entrepreneurship among their tribal members. Ngāi Tahu supports financial knowledge and economic independence among its members through the Whai Rawa scheme, a hybrid between a superannuation scheme and a unit trust, in which they match savings 4:1 for children and 1:1 for adults (Te Rūnanga o Ngāi Tahu, no date). Waikato-Tainui has partnered with a business incubator to provide workshops based at marae (sacred central area of a village) supporting tribal members to develop businesses. The nine-part workshop series covered topics including how start-ups work, design thinking, market validation, business modelling, marketing, finance, intellectual property (IP), governance and pitching (Waikato-Tainui 2014).

The Māori economy has been valued in excess of NZ\$36 billion (BERL 2011a) and a number of reports have begun assessing the contribution of Māori to regional economies (BERL 2012; TPK 2014). Māori are playing an increasingly significant role in the New Zealand economy through participation in the workforce, contribution to gross domestic product (GDP) and ownership of assets. A focus on strategies for Māori economic development at the national level 
(Māori Economic Development Panel 2012), the regional level (Bay of Connections 2014) and at tribal levels has emphasised the need to extend the discourse on Māori/tribal economic development to address social and cultural underdevelopment in their communities (Smith et al. 2015). Indirect economic influence can also be exerted through resource management responsibilities and consultation mechanisms associated with economic development. Tribes are also now organised within nationally representative bodies (Te Ohu Kai Moana, iwi Chairs Forum, Federation of Māori Authorities) and engage in the formation of economic development strategies from regional to national levels as well as resource allocation policies (fisheries, aquaculture, water). To engage effectively in these activities, tribes require access to highquality technical information as well as the intellectual resources to frame policy parameters around tribal values and indigenous world views.

\section{Growing intellectual capital}

Māori intellectual capital has grown significantly over the past 30 years, with significant improvements in Māori tertiary participation, higherlevel degree completions and Māori research infrastructure. In 2013, there were over 22,000 Māori students enrolled in bachelor or higher qualifications in New Zealand institutions (Ministry of Education 2014). Māori participation in higher-level degrees has also been on the increase, with the number of Māori doctoral graduates increasing from 90 in 2001 to 311 by 2010, with a further 392 enrolled in PhD programs (NZIER 2014). The increase in Māori tertiary participation can be attributed in part to the development of Māori tertiary providers (for example, Te Whare Wananga o Aotearoa, Te Whare Wananga o Awanuiarangi, Te Wananga o Raukawa), Māori research centres within tertiary institutions and the Māori Centre of Research Excellence (Nga Pae o te Maramatanga). The increase in Māori intellectual capital has led to an employment shift from trades to professions and business as well as generating a number of Māori professional networks (for example, Māori Medical Practitioners Association, National Māori Accountants Network, The Māori Law Society, National Network of Māori Design Professionals). The increase in higher degree completions has provided intellectual capacity to direct towards Māori research, which has been facilitated by Māori-specific funding mechanisms- 
for example, Rangahau Hauora Māori ${ }^{3}$ and the Vision Mātauranga Capability Fund (Ministry of Science and Innovation 2016) - and policy settings that support Māori participation within the research sector, including collaborative investment mechanisms such as the National Science Challenges. While the policy focuses on unlocking the science and innovation potential of Māori knowledge, people and resources for New Zealand's benefit, tribal interest in research is aligned to realising their own aspirations, including the opportunities that arise from engaging with the knowledge economy through science and innovation (BERL 2011b; Harmsworth 2011; Nana et al. 2012).

\section{Growing opportunities for indigenous knowledge}

The Māori renaissance has gained momentum in Aotearoa/New Zealand over the past 40 years. Its initial focus was on Māori language, but has since spread to a range of cultural practices, art forms and areas of expertise that collectively represent their indigenous knowledge or mātauranga Māori. This renaissance has had at its heart the revitalisation and rejuvenation of traditional knowledge bases (Royal 2009), including not only efforts to preserve and maintain traditional resources, but also the right to advance and develop them (Gibbs 2005). Māori studies departments in universities refocused research on Māori culture and traditions towards cultural regeneration, creating opportunities for indigenous knowledge to become a part of the academy. Research to inform Waitangi Tribunal and Treaty settlement processes has provided tribes with repositories of indigenous knowledge that can be used for other purposes. However, indigenous knowledge is not just the domain of tribal entities. Networks of practitioners in traditional medicine, non-instrument navigation, cultural performance, traditional arts and cultural tattoo cross tribal boundaries and support the restoration of tribal histories and practices. Many of these practitioner organisations have interests in supporting education and training initiatives as well as research and commercial applications and have begun thinking about their role as stewards of indigenous knowledge (Boulton et al. 2014). The growing role and economic influence of iwi as well as the growing intellectual capital in the Mãori community are creating additional opportunities to apply indigenous knowledge to a range of domains including resource management, health research and entrepreneurial activities.

3 Health Research Council of New Zealand: hrc.govt.nz/. 
The presence of indigenous brands also speaks to the way in which indigenous knowledge is being used to inform and support commercial activities, providing greater diversity and richness of experience in the marketplace (Jones et al. 2005).

Mātauranga Māori can be defined as the unique Māori way of viewing the world, encompassing both traditional knowledge and culture' (Waitangi Tribunal 2011), reinforcing the view that knowledge emerges from the land, defining both our relationship with it and our responsibilities towards it. It is in the environmental space that opportunities for mātauranga Māori are being advanced, with the development of Māori frameworks, approaches and models to support environmental decision-making and monitoring (Awatere \& Harmsworth 2014). Through the increasing range of cogovernance and comanagement relationships, tribes are asserting the importance of including indigenous knowledge as an information source in environmental decision-making (Hudson et al. 2016). Some examples of cultural indicators, monitoring frameworks and assessment tools utilising mātauranga Māori include the Cultural Health Index for streams and rivers, State of the Takiwa, Mauri Model, cultural indicators for wetlands and iwi estuarine toolkits (Nelson \& Tipa 2012).

\section{New Zealand's data future}

There are a number of challenges for iwi in accessing good-quality data. Limitations in infrastructure and people-capacity constrain the amount and quality of the data iwi can collect and manage independently. Governments collect a vast amount of data about iwi members; however, there are limited opportunities for iwi to access these information sources. This is due in part to the variable quality of ethnicity data (Kukutai \& Walter 2015) and the absence of iwi affiliation in many data sources. Using a health analogy, it could be said that iwi suffer from inequities in data access and inequalities in data infrastructure.

However, this picture may change with the establishment of Statistics New Zealand's Integrated Data Infrastructure (IDI) (Statistics New Zealand, no date). The IDI is a linked longitudinal dataset that currently includes economic, education, justice, health and safety, migration, tenancy and business data. It has been created to support research, analysis and policy evaluation on transitions and outcomes for people. 
The IDI can be accessed by approved researchers and used within a 'five safes' framework that ensures access to micro-data is provided only if all of the following conditions can be met:

- safe people - researchers can be trusted to use data appropriately and follow procedures

- safe projects - the project has a statistical purpose and is in the public interest

- safe settings - security arrangements prevent unauthorised access to the data

- safe data - the data inherently limit the risk of disclosure

- safe output - the statistical results produced do not contain any disclosing results.

The creation of the IDI supports the government's intention to harness the economic and social power of data (New Zealand Data Futures Forum 2015ab). New Zealand's digital future is dependent on a data revolution and the expectation that data will be more abundant and ubiquitous, connecting people, places and things. It is also anticipated that the widespread use of 'big data', where data are used, reused, processed and reconfigured, will fundamentally challenge legislative frameworks around privacy and information. Definitions of 'personal information', the role of consent and individual control and principles of data minimisation and purpose limitation will come under pressure during this data revolution (New Zealand Data Futures Forum 2015b). The New Zealand Data Futures Forum suggests that data should be recognised as a strategic asset for New Zealand and that we need to develop new ways to achieve trust and privacy in an environment where institutions should manage data use rather than focus on data ownership. The four principles they proposed for safely managing and optimising the use of data are:

1. Value: New Zealand should use data to drive economic and social value and create a competitive advantage for the country.

2. Inclusion: All parts of New Zealand society should have the opportunity to benefit from data use.

3. Trust: Data management in New Zealand should build trust and confidence in our institutions.

4. Control: Individuals should have greater control over the use of their personal data (New Zealand Data Futures Forum 2015b). 
The importance of data and its role in future health care have emerged from discussions with tribes being conducted as part of a research project exploring Māori views on biobanking and genomic research. ${ }^{4}$ While the focus of the project has been primarily on the safe collection and use of human tissue, the tribes considered that the genetic data produced from human tissue must also be protected. Participants understood the increasingly complex nature and changing expectations of data use, which see personal information (genetic data, clinical records) being used in a public domain to improve services, but often to private or corporate advantage. The participants recognised that data are a strategic asset for Māori, especially as they are becoming an increasingly valuable resource. They also felt that individuals and tribes have rights to the tissue and raw data as well as interests in any research or applications of those data. The genetic data, while a blueprint for an individual, are also representative of the collective and there exist both individual and collective rights and interests in the information - a position that has led to the development of a tribal agreement on the use, storage and protection of genome-wide sequence data. ${ }^{5}$

\section{Informing tribal data sovereignty}

As governments look to reform the nature of relationships, rights and responsibilities relating to data between individuals, businesses and the state, there is a growing awareness that ensuring indigenous participation in the knowledge economy and a data-rich future will inevitably lead to a discussion about indigenous data sovereignty and establishing the nature of tribal rights to and interests in different sources of data. Tensions around the relative rights of individuals and collectives that have long pervaded Māori critiques of Western ethics are likely to re-emerge in the discussion about principles to underpin data use and management (Hudson et al. 2010). Issues of individual

4 Te Mata Ira: Culturally Informed Guidelines for Biobanking and Genomic Research is an interdisciplinary research project funded by the Health Research Council.

5 Ngati Porou Hauora have developed this agreement with Associate Professor Tony Merriman from the Department of Biochemistry at the University of Otago to store computer data at the University of Otago from the Genetics of Gout in Tairawhiti and the Genetics of Gout and comorbidities: genes and environment research projects. 
and collective consent, Māori involvement in governance mechanisms and what constitutes personal, iwi and state rights and interests in data will be the crux of negotiations. Tribal positions are likely to be informed by a number of areas, including cultural and indigenous intellectual property rights, indigenous research ethics and existing resource rights.

\section{Indigenous cultural and intellectual property rights}

Iwi are developing their own views about culturally appropriate management and use of data, most often in relation to their own data sources and indigenous knowledge. The Mataatua Declaration on the Cultural and Intellectual Rights of Indigenous People emerged from an international conference held in 1993 and was written in response to indigenous concerns about the exploitation of their knowledge and resources (IRI 1997). The Mataatua Declaration reaffirmed Māori rights to self-determination, recognition as the exclusive owners of their cultural and intellectual property, the importance of ensuring the first beneficiaries of indigenous knowledge are the direct indigenous descendants and that all discrimination and exploitation of indigenous peoples, indigenous knowledge and indigenous cultural and intellectual property rights must cease. These ideals have been reinforced by the United Nations Declaration on the Rights of Indigenous Peoples (UNDRIP) (UN 2007), which codifies historical indigenous grievances, contemporary challenges and sociopolitical, economic and cultural aspirations. Article 31 speaks directly to intellectual property and indigenous control over data and information:

Article 31: Indigenous peoples have the right to maintain, control, protect and develop their cultural heritage, traditional knowledge and traditional cultural expressions, as well as the manifestations of their sciences, technologies and cultures, including human and genetic resources, seeds, medicines, knowledge of the properties of fauna and flora, oral traditions, literatures, designs, sports and traditional games and visual and performing arts. They also have the right to maintain, control, protect and develop their intellectual property over such cultural heritage, traditional knowledge, and traditional cultural expressions. (UN 2007) 


\section{Indigenous research ethics}

Research also provides a context from which a number of conversations about tribal rights and responsibilities for protecting indigenous data have emerged. Frameworks for indigenous research (Smith 1997: 526; Smith 1999) and indigenous research ethics (NHMRC 2003; Ermine et al. 2004; Hudson et al. 2010) speak directly to issues of access, use of indigenous knowledge and the responsibilities of collectives in managing and protecting that information. The principles of ownership, control, access and possession (OCAP $\left.{ }^{\circledR}\right)$ also inform indigenous best practice and reflect self-determination in research for aboriginal and First Nations communities in Canada (Schnarch 2004; FNIGC, this volume). 'Ownership' refers to the relationship between indigenous communities and their cultural knowledge, data or information. It asserts community ownership of information and recognises stewardship as the mechanism by which ownership is asserted. 'Control' asserts the right for indigenous communities to control all aspects of research and information management processes. 'Access' refers to the right to have access to information and data about themselves and their communities (which others hold), as well as to make decisions about access to collective information (which they hold). 'Possession' is a counterpoint to past experience of data misuse and represents a key mechanism through which ownership can be asserted and control maintained.

While the OCAP ${ }^{\circledR}$ principles have been developed for the research context, they also reflect fundamental considerations that tribes will expect to be recognised within any data-sharing environment. Affirming tribal sovereignty is a core focus of the National Congress of American Indians. Through their Policy Research Centre, they have commented on the Draft National Institutes of Health Genomic Data Sharing Policy, including the role that traditional laws and appropriate research have in informing the policy. They highlighted five overarching points that are relevant to this discussion, including:

- Tribal nations have sovereignty over research conducted on tribal lands and with tribal citizens.

- Researchers must secure active tribal approval for the collection, use and sharing of tribal data. 
- There are successful models of tribally driven data sharing that serve to both protect and benefit native people.

- Research ethics need to acknowledge the importance of community consent alongside individual consent.

- Research ethics need to include protections for biological samples collected from both living and deceased human beings. ${ }^{6}$

\section{Resource rights and interests}

A unique aspect of the treaty environment in New Zealand is the ability to submit claims to the Waitangi Tribunal for contemporary grievances relating to any enactment, policy or practice adopted or an act done or omitted by the Crown after 21 September 1992 that breaches the Treaty of Waitangi (Chen 2012). Over 200 contemporary claims have been filed, some of which have led to significant settlements with the Crown, including:

- The Māori Fisheries Act 1989, Treaty of Waitangi (Fisheries Claims) Settlement Act 1992 and Māori Fisheries Act 2004, which granted Māori NZ\$150 million and effective control over one-third of New Zealand's commercial fishery.

- The Māori Commercial Aquaculture Settlement Act (2004), which granted Māori 20 per cent of the aquaculture space created after 1992, covering pre-commencement space (before 2005) and new space (2005 onwards).

- The Crown Forests Asset Act (1989) transferred Crown forests to state-owned enterprises while protecting the claims of Māori under the Treaty of Waitangi. The Crown Forestry Rental Trust was established to manage the annual rental fees from Crown licensed forest land until the beneficial owners have been determined. Since 1990, it has facilitated the settlement of Māori claims by providing assistance to tribes who have Crown forests within their claimant area to prepare, present and negotiate their settlements. This included the 'Treelords' settlement, which returned NZ\$195.7 million of Crown forest land and NZ\$223 million in accumulated rentals to seven tribes in the central North Island (NZPA 2008).

6 National Congress of American Indians, comments on Draft NIH Genomic Data Sharing Policy, 20 November 2013. 
- Claims over radio spectrums led to the reservation of space for Māori radio stations, Māori television and the establishment of a Crown funding agency, Te Mangai Paho. The evolution of technology and commercialisation of other spectrums also resulted in NZ\$5 million being provided to the Te Huarahi Tika Trust to enable Māori a right to purchase 3G radio frequency spectrum in 2000. Te Huarahi Tika Trust also supported claims for $4 \mathrm{G}$ spectrum, which were ultimately unsuccessful.

- The Waitangi Tribunal's WAI262 report on the flora, fauna, cultural and intellectual property claim (Waitangi Tribunal 2011), which took 21 years to complete, made a number of recommendations including the development of a treaty-compliant bioprospecting regime; however, the Crown has yet to respond.

- Māori rights and interests in relation to fresh water have been the subject of recent claims prompted in part by the partial privatisation of energy companies with hydroelectric and geothermal resources. Arguments have been made to the Waitangi Tribunal and the Supreme Court that Māori have proprietary interests in water and the government has indicated it would work towards recognition of Māori water rights on a catchment-by-catchment basis (Radio NZ 2015). Māori positions are being informed by elements of previous settlements, collaborative water reform processes (Land and Water Forum 2012) and advocacy from the Freshwater iwi Leaders Group. ${ }^{7}$

Settlements have often been prompted by the privatisation of Crown assets or the establishment of regulatory processes that create proprietary interests for the rights-holders (that is, fish quotas, radio spectrum). A feature of these settlements has been their pan-tribal nature, which has resulted in the creation of Māori entities to grow the settlement assets and work out appropriate distribution models (for example, Te Ohu Kai Moana, Crown Forestry Rental Trust, Te Huarahi Tika Trust).

7 Iwi Chairs Forum: iwichairs.maori.nz/. 


\section{Establishing tribal rights and interests in data}

If the primary role of a tribe is to sustain its people by maintaining its resources and culture across generations then how do data and information support the expression of this self-determination across political, cultural and economic domains? Te Whakatōhea provides one example of how $i w i$ are considering the issue of indigenous data sovereignty in the context of their information needs and development aspirations.

Whakatōhea are located in the eastern Bay of Plenty region of New Zealand and have approximately 12,000 tribal members. Their primary genealogical connections associate the $i w i$ with two ancestral voyaging canoes, the Nukutere and Mataatua. Their tribal boundaries surround the township of Opotiki in the Bay of Plenty, extending eastwards from Ohiwa Harbour to Opape along the coastline, and inland to Matawai. These lands have long held an abundance of food resources, particularly seafood, and most settlements are located near the coast. Whakatōhea's history of land confiscations (raupatu) from the early 1800s led to a series of events involving the loss of an economic base and the destruction of social structures, both of which had a devastating impact on tribal identity, culture, economy, health and wellbeing.

The Whakatōhea Māori Trust Board was established in 1947 and recognised in legislation in 1955 when the Māori Trust Board Act came into effect. The board was given functions under section 24 of the Act, including to: administer Whakatōhea's assets, promote health, economic and social welfare and educational and vocational training (Walker 2007). The board is the largest employer in Opotiki, with over 90 staff across its commercial, education, health and social service activities. The board has commercial interests in forestry, dairy farming, kiwifruit and property and is the majority partner in Eastern Seafarms Limited, which holds the consent for 3,800 ha of water space. Through the Whakatōhea Fisheries Trust and Asset Holding Company, it is the mandated iwi organisation for the settlement of fisheries assets and, through Te Wheke Atawhai Limited, it manages a GP clinic, health and social services as well as an education unit. 


\section{What is driving Whakatōhea's interest in data?}

The vision for the Whakatōhea Māori Trust Board is represented in the whakatauki (tribal saying) 'Ko te kai hoki $i$ Waiaua', which translates as 'To be the food bowl that feeds the world'. The board has developed 50-year economic, education, environmental, social, health and cultural plans focusing on community transformation to restore Whakatōhea's mana (prestige/power), wellbeing and economic strength. It also has a wide portfolio of commercial interests in the horticulture, farming and property sectors that require high-quality information and expertise to support sound financial investments. The board has recognised that quality data are the foundation for robust decision-making and this is now being actively promoted across the entire range of its activities. Information is being collected through research, administrative systems and collection of historical documents. Examples of research include:

- A comprehensive iwi health survey, He Oranga o te rohe o te Whakatōhea Wellbeing Survey 2010, involving face-to-face interviews with 750 registered adult members of Whakatōhea living in the Opotiki district.

- An aquaculture research strategy to prepare Whakatōhea to engage in research and development as well as identify opportunities for future development of consented and (currently) nonconsented species in the 3,800 ha of marine space they manage.

- Research to better understand how Māori values inform investment decisions for collective assets so the tribe can be more transparent in the way it applies Whakatōhea values and indigenous corporate responsibility into their decision-making processes (Hudson 2014; Hudson \& Farrar 2015).

- The integration of practice models grounded in mātauranga Māori (indigenous knowledge) has broadened the focus of professional development from technical competency into areas of cultural competency, creating a number of direct benefits (Haring et al. 2015).

Information systems support human resources, information technology, finance, quality management, asset management and communication across the board's business groups. A new customer 
relationship management database system is being developed to enhance operational-level access to relevant information about clients and their family. Tribal information including tribal minutes, Māori land court minutes, maps and stories dating back to the early 1800s are captured on a separate server to create a digital archive. Communication systems allow the trust board to connect with its people and share information. Significant investment has been undertaken with a revamp of the website, Facebook page, internal rebranding and promotion of events including tribal elections and updates on the treaty settlement process.

\section{Conceptualising tribal rights and interest in data}

So what does all this mean for Whakatōhea and how might data sovereignty support their development? To realise their strategic aim - 'Ki te whakarangatira inga uri o Whakatōhea' ('to lift our nation, and to grow and invest in the wellbeing of our people') - Whakatōhea will require access to data and information as well as information systems and the capability to operate them (Whakatōhea Māori Trust Board 2011).

Whakatōhea have already realised that improving data connectivity within their organisation across diverse activities enables better service delivery. They expect that access to government data about their tribal members would also enhance their ability to provide services to tribal members. Access to the complete range of data allows the tribe to interpret information in more positive and productive ways, providing a counterbalance to the disparity-focused reports that are regularly produced by researchers. It would also allow them to create stronger networks and opportunities for tribal members living outside the tribal boundaries and consider how best to provide services, access to skills and connections and to build capacity. Access to government-collected data will enhance their ability to participate in nation-building activities for both Whakatōhea and Aotearoa/ New Zealand. Building a stronger and more connected tribe is an important goal as 90 per cent of the tribal population lives outside their traditional lands. 
Whakatōhea consider that access to government-collected data and information is a treaty right and that the tribal entity is better placed to create benefit for tribal members than government departments or research organisations. They argue that the acknowledgement of whakapapa (tribal genealogy) creates rights and responsibilities, including establishing a social contract for tribal entities to serve their people. Access to information is a foundation for establishing appropriate services or activities. Whakatōhea recognise the sensitivity of, and need to appropriately manage, data and have done so effectively as part of the delivery of health and social services to the wider community. Moving into the collection of data for tribal members who are not users of their health and social services prompts the question, should a consent to connect with the tribe on the tribal database translate to a consent to access government administrative data? Or, alternatively, if tribal affiliation is listed in government datasets, should tribes have access rights to de-identified data in the same way that researchers do?

Table 9.1 Data sovereignty: articulating tribal rights and interests for Whakatōhea

\begin{tabular}{|l|l|}
\hline Rights and interests & Type \\
\hline Exclusive rights & $\begin{array}{l}\text { Indigenous knowledge } \\
\text { Client relationship management data } \\
\text { Commercial intellectual property } \\
\text { Genetic data-tribal members and indigenous flora }\end{array}$ \\
\hline Shared rights & $\begin{array}{l}\text { Central government administrative data } \\
\text { Service-level information created by tribal entities }\end{array}$ \\
\hline Shared interests & $\begin{array}{l}\text { Research outputs } \\
\text { Government and agency reports } \\
\text { Commercial activities }\end{array}$ \\
\hline
\end{tabular}

Source: The authors.

As shown in Table 9.1, Whakatōhea recognise the reciprocal nature of some forms of data and understand that some information will be shared and rights to other types of information could be more exclusive. From a tribal perspective, exclusive rights exist around culturally or commercially sensitive information and would include indigenous knowledge, client relationship management data, commercial intellectual property and genetic data arising from tribal members and indigenous flora. Shared rights exist around information that supports the development of funding streams or service improvements for tribal members, which might consist 
of service-level information relating to government-funded activities. Tribal services provide this information to government agencies but would like access to information about additional tribal members that these agencies collect. Shared interests arise from the outcomes of the use of tribal information (exclusive or shared) by ensuring that the tribe can benefit from opportunities to develop relationships or partnerships that advance their interests through research outputs, government reports or commercial activities. The tangible expression of these rights to data would be the ability to influence how data are interpreted and the types of stories that are told about the tribe.

\section{Conclusion}

Tribes have increasingly complex information needs across all sectors of society and, while they are slowly raising their internal capacity and capability to collect and manage information, they will continue to rely on partnerships with government agencies and research institutions to address all their information needs. In the digital age, the old adage 'knowledge is power' is more relevant than ever. As Aotearoa/New Zealand transitions into a new data future, tribes must ensure that they can access and utilise the new data networks and infrastructures being created to realise tribal aspirations and benefit their members. Data are becoming a tangible and potentially valuable resource and many data sources are being made available for researchers to access. As data sharing becomes a normal activity, it is important that tribes articulate the nature of their treaty rights and establish appropriate boundaries for their tribal data.

\section{References}

Auckland Council (2016). Tūpuna Maunga o Tāmaki Makaurau Authority, Auckland Council, Auckland, aucklandcouncil.govt.nz/ en/aboutcouncil/representativesbodies/maungaauthority/Pages/ home.aspx.

Awatere S \& Harmsworth G (2014). Nga Aroturukitanga tika mo nga Kaitiaki: Summary review of mātauranga Māori frameworks, approaches and culturally appropriate monitoring tools for freshwater monitoring and management, Client Report LC1774, Landcare Research, Lincoln, NZ. 
Bay of Connections (2014). He mauri ohooho: our people, our wealth, our future-Māori economic development strategy, Bay of Connections, Tauranga, NZ.

Bay of Plenty Regional Council (2016). Rangitaiki River Forum, Bay of Plenty Regional Council, Whakatāne, boprc.govt.nz/council/ committees-and-meetings/rangitaiki-river-forum/.

Boulton A, Hudson M, Ahuriri Driscoll A \& Stewart A (2014). Enacting Kaitiakitanga: challenges and complexities in the governance and ownership of Rongoa research information. International Indigenous Policy Journal 5(2), doi:10.18584/iipj.2014.5.2.1.

Business and Economic Research Limited (BERL) (2011a). The asset base, income, expenditure and GDP of the 2010 Māori economy, BERL, Wellington.

Business and Economic Research Limited (BERL) (2011b). The Māori economy, science and innovation, BERL, Wellington.

Business and Economic Research Limited (BERL) (2012). Situational analysis: Māori contribution and position in the Bay of Connections economy - report to the Bay of Plenty Regional Council, BERL, Wellington.

Chen M (2012). Mai Chen: Contemporary treaty claims, 13 September 2012, Chen Palmer: New Zealand Public and Employment Law Specialists, Wellington, chenpalmer.com/news/news-articles/maichen-contemporary-treaty-claims/.

Ermine E, Sinclair R \& Jeffery B (2004). The ethics of research involving indigenous peoples, Indigenous Peoples' Health Research Centre, Saskatoon, Canada.

Gibbs M (2005). The right to development and indigenous peoples: lessons from New Zealand. World Development 33(8):1365-78.

Haring RC, Hudson M, Erickson L, Taualii M \& Freeman B (2015). First Nations, Māori, American Indians and native Hawaiians as sovereigns: EAP with indigenous nations within nations. Journal of Workplace Behavioral Health 30(1-2):14-31, doi:10.1080/15555 240.2015.998969. 
Harmsworth G (2011). Māori perspectives on the science and innovation system. New Zealand Science Review 68(1):45-8.

Hudson M (2014). Optimising the Māori in Māori economic development: how Māori values inform investment decisions for collective assets, Case study report, Whakatōhea Māori Trust Board, Opotiki, NZ.

Hudson M \& Farrar D (2015). Optimising the Māori in Māori economic development: how Māori values inform investment decisions for collective assets, Case study report II, Whakatōhea Māori Trust Board, Opotiki, NZ.

Hudson M, Collier K, Awatere S, Harmsworth G, Henry J, Quinn J, Death RG, Hamilton DP, Te Maru J, Watene-Rawiri E \& Robb M (2016). Integrating indigenous knowledge into freshwater management: an Aotearoa/New Zealand case study. The International Journal of Science in Society 8(1)(March):1-14.

Hudson M, Milne M, Reynolds P, Russell K \& Smith B (2010). Te Ara Tika guidelines for Māori research ethics: a framework for researchers and ethics committee members, Health Research Council, Auckland.

International Research Institute for Māori and Indigenous Education (IRI) (1997). Mataatua declaration on cultural and intellectual property rights of indigenous people. In Pihama L \& Waereai-te-rangi Smith C (eds), Cultural and intellectual property rights: economics, politics and colonisation. Volume 2, International Research Institute for Māori and Indigenous Education, University of Auckland, Auckland.

Jones K, Gilbert K \& Morrison-Briars Z (2005). Māori branding: a report investigating market demand for Māori cultural elements, Waka Tohu Research Project, New Zealand.

Kukutai T \& Walter M (2015). Recognition and indigenising official statistics: reflections from Aotearoa New Zealand and Australia. Statistical Journal of the IAOS (31):317-26.

Land and Water Forum (2012). Third report of the Land and Water Forum: managing water quality and allocating water, Land and Water Forum, Wellington. 
Māori Economic Development Panel (2012). He kai kei aku ringa: the Crown-Māori economic growth partnership - strategy to 2040, Māori Economic Development Panel, Wellington.

Ministry of Education (2014). Profiles and trends: New Zealand's tertiary education sector 2013, Tertiary sector performance analysis, Ministry of Education, Wellington.

Ministry of Science and Innovation [now Ministry of Business Innovation and Employment] (updated 2016). Vision Mātauranga Capability Fund: questions and answers, New Zealand Government, Wellington, msi.govt.nz/get-funded/research-organisations/ vision-matauranga-capability-fund/.

Nana G, Stoke F, Hudson M, Haar J \& Delaney P (2012). Strategic step change: Māori entities and the science sector-case studies, Report to Te Puni Kokiri, Wellington.

National Health and Medical Research Council (NHMRC) (2003). Values and ethics: guidelines for ethical conduct in Aboriginal and Torres Strait Islander health research, NHMRC, Canberra.

Nelson KD \& Tipa G (2012). Cultural indicators, monitoring frameworks and assessment tools, Report for the Wheel of Water Project, Aqualinc Research Limited, Christchurch.

New Zealand Data Futures Forum (2015a). Key recommendations and catalyst projects, Statistics New Zealand, Wellington, nzdatafutures. org.nz/sites/default/files/NZDFF_Key_recommendations.pdf.

New Zealand Data Futures Forum (2015b). Navigating the data future: four guiding principles, Statistics New Zealand, Wellington, nzdatafutures.org.nz/sites/default/files/NZDFF_Discussion \% 20 document\%202.pdf.

New Zealand Institute of Economic Research (NZIER) (2014). Research impact evaluation: NZIER report to Nga Pae o te Maramatanga, NZIER, Wellington.

New Zealand Press Association (NZPA) (2008). Govt signs \$400 millionplus 'Treelords' deal. National Business Review, 25 June 2008, nbr.co.nz/article/govt-signs-400-million-plus-treelords-deal-32500. 
Radio NZ (2015). Deadline set for freshwater deal. Radio NZ, 5 February 2015, radionz.co.nz/news/te-manu-korihi/265413/deadline-set-forfreshwater-deal.

Royal C (2009). Te Kaimanga: towards a new vision for Mātauranga Māori, Lecture 1, Macmillan Brown Lecture Series, Macmillan Brown Centre for Pacific Studies, University of Canterbury, Christchurch, 16 September 2009.

Schnarch B (2004). Ownership, control, access and possession (OCAP) or self-determination applied to research: a critical analysis of contemporary First Nations research and some options for First Nations communities. Journal of Aboriginal Health (January):80-95, naho.ca/jah/english/jah01_01/journal_p80-95.pdf.

Smellie P (2014). Tainui assets top $\$ 1 \mathrm{~b}$ as 20th anniversary of treaty settlement looms. National Business Review, 2 July 2014, nbr.co.nz/ article/tainui-assets-top-1bln-20th-anniversary-treaty-settlementlooms-bd-158582.

Smith GH (1997). The development of Kau papa Māori: theory and praxis, PhD thesis, University of Auckland, Auckland.

Smith GH, Tinirau R, Gillies A \& Warriner V (2015). He Mangopare Amohia: strategies for Māori economic development, Te Whare Wananga o Awanuiarangi, Whakatāne.

Smith LT (1999). Decolonising methodologies: research and indigenous peoples, Zed Books, London \& New York.

Statistics New Zealand (no date). Snapshots of New Zealand: integrated data infrastructure, Statistics New Zealand, Wellington, stats. govt.nz/browse_for_stats/snapshots-of-nz/integrated-datainfrastructure.aspx.

Te Puni Kokiri (TPK) (2014). Māori economy in the Waikato region, TPK, Wellington.

Te Rūnanga o Ngāi Tahu (no date). A pathway to prosperity for Ngāi Tahu Whānui, Te Rūnanga o Ngāi Tahu, Christchurch, ngaitahu. iwi.nz/whanau/whai-rawa/.

Te Rūnanga o Ngāi Tahu (2014). Annual report 2014, Te Rūnanga o Ngāi Tahu, Christchurch, ngaitahu.iwi.nz/annual-report-2014/. 
United Nations (UN) (2007). United Nations declaration on the rights of indigenous peoples, United Nations, New York, un.org/esa/ socdev/unpfii/documents/DRIPS_en.pdf.

Waikato-Tainui (2014). Waikato-Tainui, SODA Inc. partnership a boost to Maaori business, 3 September 2014, Waikato-Tainui Te Kauhanganui Inc., Hamilton, NZ, waikatotainui.com/waikatotainui-soda-inc-partnership-a-boost-to-maaori-business/.

Waitangi Tribunal (2011). Ko Aotearoa Tenei: a report into claims concerning New Zealand law and policy affecting Māori culture and identity, Te taumata tuarua [Waitangi Tribunal report], Legislation Direct, Wellington.

Walker R (2007). Opotiki Mai Tawhiti, Penguin Books, Auckland.

Whakatōhea Māori Trust Board (2011). Whakatōhea Māori Trust Board: strategic plan 2010-2015, Whakatōhea Māori Trust Board, Opotiki, NZ. 
This text is taken from Indigenous Data Sovereignty: Toward an agenda, edited by Tahu Kukutai and John Taylor, published 2016 by ANU Press, The Australian National University, Canberra, Australia. 